\title{
Correction to: Perennial Bioenergy Crop Yield and Quality Response to Nitrogen Fertilization
}

\author{
Sichao Wang ${ }^{1,2}$ (1) $\cdot$ Gregg R. Sanford ${ }^{3,4} \cdot$ G. Philip Robertson ${ }^{1,2,5} \cdot$ Randall D. Jackson $^{3,4} \cdot$ Kurt D. Thelen ${ }^{1,2}$ \\ Published online: 21 December 2019 \\ (C) Springer Science+Business Media, LLC, part of Springer Nature 2019
}

\section{Correction to: BioEnergy Research (2019) https://doi.org/10.1007/s12155-019-10072-z}

The original version of this article unfortunately contained a mistake. The author was incorrectly listed as Philip G. Robertson. It should have been G. Philip Robertson. The original article has been corrected.

Publisher's Note Springer Nature remains neutral with regard to jurisdictional claims in published maps and institutional affiliations.

The online version of the original article can be found at https://doi.org/ $10.1007 / \mathrm{s} 12155-019-10072-\mathrm{Z}$

Sichao Wang

wangsic1@msu.edu

1 DOE-Great Lakes Bioenergy Research Center, Michigan State University, East Lansing, MI 48824, USA

2 Department of Plant, Soil and Microbial Sciences, Michigan State University, 1066 Bogue Street, East Lansing, MI 48824, USA

3 DOE-Great Lakes Bioenergy Research Center, University of Wisconsin-Madison, Madison, WI 53706, USA

4 Department of Agronomy, University of Wisconsin-Madison, Madison, WI 53706, USA

5 W.K. Kellogg Biological Station - Michigan State University, Hickory Corners, MI 49060, USA 